\title{
Deliberation, Dialogue and Deliberative Democracy in Social Work Education and Practice
}

Roger A. Lohmann

West Virginia University, roger.lohmann@mail.wvu.edu

Follow this and additional works at: https://researchrepository.wvu.edu/faculty_publications

Part of the Adult and Continuing Education Commons, Nonprofit Administration and Management Commons, Organizational Communication Commons, Social and Philosophical Foundations of Education Commons, Social Influence and Political Communication Commons, and the Social Work Commons

\section{Digital Commons Citation}

Lohmann, Roger A., "Deliberation, Dialogue and Deliberative Democracy in Social Work Education and Practice" (2009). Faculty Scholarship. 800.

https://researchrepository.wvu.edu/faculty_publications/800 


\section{Deliberation, Dialogue and Deliberative Democracy in Social Work Education and Practice ${ }^{1}$}

Roger A. Lohmann

Nancy Lohmann

\section{Introduction}

The interrelated themes of public talk - deliberation, dialogue, citizen and organizational participation figure importantly in contemporary social theory and political philosophy (Barber, 1988; Elstub, 2008; Cohen and Arato, 1992; Gutmann and Thompson, 2002; Habermas, 1984;), and a number of other disciplines including contemporary public administration (Morse, 2006; Mooney \& Eikenberry, 2006; Stivers, 2000; Williams, in this volume).

What may be less clear is the unique emergence of these ideas in earlier forms as part of the formulation of social work as a field over the past century. Ideas of public talk were particularly central in the settlement house, neighborhood and community centers and related movements and in the establishment of group, community organization and social administration perspectives in social work education and practice. For several decades early in the twentieth century, the handling of these ideas in social work was what is described throughout this volume as pracademic, as practitioners like Jane Addams and Mary Parker Follett (as well as more hostile opponents like Walter Lippman) engaged philosophers like John Dewey and George Herbert Mead on these questions. The result was a rich and powerful strand of thinking that still nourishes and enriches social work thought and action in the present.

Each year, numerous proposals are put forth in the social work journals, at the Annual Program Meeting of the Council on Social Work Education and in other forums for the development of new forms of social work education and practice in new arenas. At first glance, proposals for active citizenship through greater integration of public deliberation and sustained dialogue into social work may appear to be just one more such initiative. Such a conclusion, however, would be in error.

Far from representing any departure from a non-deliberative social work past, greater emphasis on public deliberation and sustained dialogue in social work education and practice would represent an embrace and continuation of a well-documented past: an affirmation of the history of the field and

\footnotetext{
1 This is an author's preprint, a revised and edited version of which is published later as Chapter 18, Lohmann \& Van Til (2011).
} 
expressions of some of its most basic principles. One preliminary evidence of this is the way in which the social work formula of "the individual in their social environment" not only brings together psychological and sociological perspectives, as is often noted. At one level, this is not unique. The same may be said for social psychology. Unlike that field, however, the social work construction of individual-in-environment also explicitly incorporates a civic or what today might be called a civil society dimension. That dimension together with social work values on human growth and development explicitly connotes the idea of a citizen-individual in a civic environment of rights and responsibilities that directly fits the "civic republican" conception of a self-regulating (or "autonomous") individual in a self-regulating (or "democratic") community. This configuration is so basic and so deeply woven into the core of the social work view of the world that there is no need to make constant reference to it.

As a result of this legacy, fundamental notions of deliberation and dialogue are so deeply woven into the fabric of social work education that it would take a major reconstruction of the field to remove them.

The foundations of modern social work theory and practice are built in fundamental ways on a base of not one, but several early models of deliberation and dialogue, together with a plurality of models of group process and at least two models of deliberative democracy that arose during the progressive era (1889-1918). ${ }^{2}$ Continuously since that time, individuals and groups within social work have continued to build on this vital core in various ways. Some of these contributors were more successful than others, several have suffered from neglect, and most are very difficult to properly assess and integrate fully into the contemporary profession of social work.

In some respects, social work interest in the full range of civil rights movements for racial and ethnic minorities, women, mentally ill, handicapped and disabled persons, gay, bisexual and transgendered persons and others have all been, in part, efforts to give civic voice to those who are silent. And most such efforts have also had a strong public deliberative core. The issue was not just one of what can our elected leaders do differently, as models of representative democracy imply. It was a question of what can we, as active, engaged citizens do to make our world a better place. This may involve advocacy, of course, to influence elected officials. But, as the long history of interest in workplace democracy in social work attests, it is also a question of more active forms of civic engagement.

For example, although the "maximum feasible participation of the poor" and welfare rights initiatives of the 1960s (both of which were deliberative in

\footnotetext{
${ }^{2}$ We will deal in this chapter with only two of the most fundamental. Others, including Robert Woods, Eduard Lindemann, Ralph Kramer and a brace of other community organization, group work and education theorists, are not at all hard to identify. The biggest problem here is simply the sheer length of the list.
} 
nature) have been widely and loudly condemned as failures by neoconservatives, many of the associated ideas of participation, involvement and empowerment - of clients, customers and citizens - have continued to exercise strong motivation for many people in social work the present moment at least as much as they have for those in other fields interested in "citizen participation" and "deliberative democracy" issues. ${ }^{3}$

Curiously, its continuing deliberative and democratic base has sometimes lent to social work an air of instability and incoherence to outsiders that has not only obscured these deliberative origins, but also demonstrated some of the very theoretical problems that are still unresolved in deliberative democracy theory. ${ }^{4}$ For example, the continuing proliferation of proposed new forms of social work practice and new client groups as noted above, usually far outstrips the ability and resources of social work to respond fully to the abundance of ideas and proposals arising from so many directions. In this context, ideas are seldom rejected; most just fail to generate sufficient interest. In some respects, this brings to mind criticisms of the alleged inability of deliberative democracy to reach definitive decisions. ${ }^{5}$

Social work has never just been a consumer of deliberative ideas arising elsewhere, however, as practice models positioning it as an applied consumer of more basic social science and theory would imply. In fact, several of the most fundamental ideas associated with deliberative democracy theory arose directly out of social work practice experience and continue to function in different forms within contemporary social work theory and practice. In social group work and community practice, in particular, one can easily find selfconscious continuity of some of the earliest theoretical traditions. ${ }^{6}$ But they are also deeply interwoven in ways almost too numerous to identify in the basic fabric of the contemporary profession and practice of social work.

\section{Basic Approach}

\footnotetext{
3 'Certifying' these failures was one of the important dynamics in early neo-conservative intellectuals like Irving Kristol, Daniel Patrick Moynihan, Nathan Glazer and neo-con publications, particularly The Public Interest.

${ }^{4}$ Elstub, (2008), especially Chapter 2 offers a careful and extensive consideration of the theoretical weaknesses and problems of deliberative democracy theory. But it is not an easy read.

${ }^{5}$ Elstub (2008) speaks of this as the "infinite regress" of "preference formation".

6 The social work literature is rich with insights into this continuity. In the group work area, for example, see Alex Gitterman, 2004. "The Mutual Aid Model," Handbook of Social Work With Groups. Charles Garvin, Lorraine M. Gutiérrez and Maeda J. Galinsky, eds. Guilford Press. 93110. Gitterman cites three sources that he says "provided group work with its philosophical base": Mary Parker Follett (both the 1924 and 1926 editions of The New State), Eduard Lindeman, a social work faculty member widely regarded as the 'father' of adult education, and the progressive education movement, inspired by the philosopher John Dewey with its emphasis on group process and peer learning.
} 
The remainder of this chapter will point to the role of deliberative perspectives in early twentieth century social work and highlight a few key people from whom much of the deliberative posture in social work emerged. It will also be shown that these early initiatives have continued to define and inspire components of contemporary social work. Central in this emergence were intellectual leaders of the intertwined community centers, social group work and settlement house movements who, even as they inspired others outside social work ${ }^{7}$, also contributed to the rise of a distinct pracademic environment of social work that has continued to foster and nurture crucial ideas on dialogue and deliberative democracy down to the present day.

Beginning in the first decades of the twentieth century, important ideas about the nature of social groups and group process, the importance of communication as something more than simply message transmission and a fundamental group-democratic orientation arose and were blended with the still-challenging pragmatic idealism of seminal figures like Jane Addams and Mary Parker Follett as well as literally dozens of their supporters, followers and contemporaries. ${ }^{8}$ While it would be easy to reconstruct this history as the emergence of practice from the theoretical work of philosophers - notably John Dewey, but also Josiah Royce and the beavy of idealists like T.H. Green and Bernard Bosanquet associated with the origins of the British welfare state - reconstructing this history as a one-way transfer from ideal thought into practice seriously distorts the actual history and downplays the independent creative contributions of Addams, Follett and other pracademics. It should be clear that the democratic nature of group process has been at least as fully and fundamentally realized over a longer period of time in social work as in any other discipline, profession or field of practice.

This volume has been positioned as an interdisciplinary text in a social work series for good reason. Several of the authors have no formal connection with social work, and some of them undoubtedly have other projects in mind and may even be uncomfortable with suggestions of the historical importance of social work to the deliberative tradition. If so, the characteristic response is a familiar one: Let's talk about it. The legitimacy of differing points of view has been one of the strengths of the social work tradition for a very long time and one that has direct deliberative origins.

\footnotetext{
7 See, for example, Fisher, Nackenoff and Chmielewski (2009)

8 "Pragmatic idealism" refers to the multiple, subtle, and at times vague and even inchoate, ways in which several generations of social workers translated into practice their understandings of the philosophical idealism of Hegel, the British idealist tradition of Thomas Hill Greene, Bernard Bosanquet and others, the American idealist tradition of Josiah Royce and the early John Dewey, the pragmatism of the later Dewey as well as assorted Marxian and Freudian perspectives, the sociology of Tönnies (community), Weber (organization), Parsons and dozens of others. This Rube Goldberg mélange of a discipline sometimes leaves purer theoreticians of the older traditions of the academy agog, but it yields workable combinations in practice. This unique mix enlivened early social work and still characterizes (and in some respects, one is tempted to also say haunts) contemporary social work thought.
} 
The response to the social work record in this regard in the wider academic and intellectual community remains mixed, which is in itself unfortunate. One can search high and low in political philosophy and social theory for anything more than hesitant, half-hearted, and grudging recognition that anyone in social work ever gave a moment's thought to these questions. Characteristically, such recognitions are often encapsulated, like the single sentence noting that Mary Parker Follett's The New State, a major work of political theory, was grounded in her experience in a social work movement. Even so, the social work record is not entirely free of blemish. Some of the implications of the dialogical perspective have proven, and continue to prove, challenging for social work education and practice as well, and not everyone in the field is comfortable with these ideas. ${ }^{9}$ One issue that proves especially vexing for contemporary social work education is whether there can be a single preferred "method", technology or proper protocol that defines the right way or best practice for a free and enlightened group of people to engage in dialogue or deliberation with one another. ${ }^{10}$ Is the choice of how to conduct a discussion entirely up to the members in a particular group setting? Or, can someone outside the situation (whether a methodologist, philosopher or theorist) prescribe the right way for citizens to engage one another in deliberation and what criteria deliberators ought to use to evaluate their own performance? Certainly, room must be allowed to learn from past experience. However, the line between benefitting from past experience and proscribing future conduct often proves a very difficult one to walk.

Another question that plagued Jane Addams among others and remains unresolved is the extent to which any robustly deliberative democracy worthy of the name can be claimed to be the unique province or professional base of any group or profession. ${ }^{11}$ This is true not only for ideas, but for people as well: Major questions arise about the extent to which exclusive labels like "social worker", "sociologist", "educator" or "philosopher" can be successfully pinned on historic figures in this area like Jane Addams, Mary Parker

\footnotetext{
9 These elements and the associated qualitative, interactional and constructivist tendencies of the social work tradition have been particularly vexing for those who have sought to separate social work from its tradition and move it 'forward' in behaviorist, positivistic, and 'more scientific' directions such as current "best practices", "performance management" and "evidence-based practice" initiatives. A broad tolerance for apostasy is one of the characteristic features that contemporary social work inherited from its deliberative traditions.

${ }^{10}$ This issue is an important one not only for social work. Others, such as members of the interdisciplinary (and, in some respects, non-disciplinary) National Conference of Deliberation and Dialogue confront similar questions regularly. A logically and theoretically consistent answer would be that it is not: That a consistent deliberative stance requires that genuinely free groups must be free to select their own processes and criteria. (For example, to reject efficiency and effectiveness even as those standards are pressed upon them by non-members.)

${ }^{11}$ Amy Gutman and Dennis Thompson. (2002) Deliberative Democracy Beyond Process", Journal of Political Philosophy. 10. 2. 153-174, offers a major political-theoretic analysis that speaks directly to this issue.
} 
Follett, John Dewey or the still-largely unknown L.J. Hanifan, who is introduced below.

\section{Pracademic Origins}

From the vantage point of contemporary social work, we can easily identify several original formulations of the ideas of deliberative democracy and they all were pracademic ones. The question of getting beyond traditional representative democracy was not originally posed and answered by social or political theorists or academics as so much current work on the topic appears to suggest. ${ }^{12}$ It arose instead in the early twentieth century context of Progressive era social work and education, by key figures seeking to put the own ideals into practice, and to reflect upon, understand, evaluate and explain the resulting practice experiences. ${ }^{13}$ Important pracademic work on deliberation and dialogue by Jane Addams, and numerous other less wellknown figures, including Mary Parker Follett, Robert Woods, L.J. Hanifan and others proceeded from a consistent desire to identify and practice new forms of democratic behavior. This work occurred simultaneously with, influencing and being influenced by the philosophical writings of John Dewey in particular (Dewey, Morris and Shapiro,1993; Westbrook, 1991). This pattern is quite different from the theory-into practice-flow of later practitioners and more abstract and general political or social theory on the subject.

Among those attempting to work out theoretical answers to the most fundamental questions of deliberative democracy, the highly original pracademic work occurring within progressive era social work should constitute an important resource. Instead, the context in which the insights of Jane Addams arose, for example, have been almost entirely ignored by both practitioners and theorists (including, in some cases, social worker educators and researchers seemingly unfamiliar with their own traditions.). ${ }^{14}$

\footnotetext{
${ }^{12}$ Even in the current era, pracademics continue to be important on this topic, often in the guise of "public intellectuals". Thus, for example, Jürgen Habermas has, for the past four decades, not been content to speak only to philosophers and sociologists but has also been a major public force in German (formerly, West German) public opinion through many newspaper and magazine articles, public speeches and lectures and other media. (As far as we know, Habermas has not been a blogger.)

${ }_{13}$ Program evaluation methodology, of course, is a more recent invention. I mean to suggest here evaluation as the psychological and social process of reflection and thought which characterized the work and writing of progressive-era social workers.

${ }^{14}$ It is hard to know the extent to which writing social work out of the deliberative democracy tradition has been deliberate. Some of the alternative explanations that come readily to mind are rather egregious and unflattering: It might be due, for example, to lack of learning and unsound scholarship or, perhaps, remarkable degrees of disciplinary parochialism. Just to cite two of many possible examples, although groups get more than a dozen mentions, for example, in the index of Elstrub (2008), Towards a Deliberative and Associational Democracy, Jane Addams, Mary Parker Follett and social work completely fail to make the index, and John Dewey each get one brief, passing mention. The terms social work and social welfare do not appear either in the index of
} 
The reasons for this are unknown. They may be nothing more substantial than indifference, sheer lack of familiarity, or the fact that the sometimes florid and idealistic language in which Addams, Follett (not to mention the British idealists) and many others of the period expressed themselves runs counter to the flat realism and grates on the modern ear. John Dewey has long been accused of being "difficult" to read for this very reason.

Whatever the reasons, nowhere is this neglect more disconcerting than in Mary Parker Follett's highly original theory of group, neighborhood and the political state, which those few who acknowledge her work all agree grew directly out of her social work practice experience in the Roxbury neighborhood of Boston from 1900-1908, and led to her later, equally original work on organizational democracy in administration/management theory. Instead of using her to get a leg up on their own interests, a variety of contemporary theorists of deliberative democracy appear to believe (or wish the reader to believe) that theirs is entirely original work. Nearly eighty years after Mary Parker Follett first laid out similar connections in The New State, recent work by a political theorist (Elstrub, 2008) highlights secondary associations (groups) as a suitable infrastructure for deliberative democracy without a single mention of Follett or The New State. Even Jürgen Habermas, whose work is otherwise deep, wise and thorough cannot be entirely excused from this tendency. Nor can social work. A great deal of Follett's highly original point of view has been incorporated into the core of contemporary social work and social administration theory largely without attribution. ${ }^{15}$

Sadly, neglect of progressive-era social work in deliberative democracy theory has been so complete and thorough in our time that it would require an entire volume just to document the omissions. At the same time, the contemporaneous orientation and lack of historical insight among practitioners of deliberation and dialogue is no different from practice in many other arenas. For example, the "core principles" of public deliberation identified by a group of practitioners in 2008 endorse principles that any assembly of group and community social workers would have been completely comfortable with seventy-five years ago. (See Appendix C for the text of this code.)

The next section recounts briefly the better-known contributions of Jane Addams and examines more fully the lesser-known but direct contributions of

the Fischer, Nackenhoff and Chmielewski (2009) volume entitled Jane Addams and the Practice of Democracy, even though the latter does appear in one chapter title.

15 There are, of course, at least exceptions to the neglect of Mary Parker Follett's unique contributions scattered throughout social work publications since her time. For example, Myron Weiner's Human Services Management text (1990) devoted a whole case study vignette to Follett's work in both editions of that book. Naturally, the emphasis was primarily on her thirdcareer management efforts. As often occurs, however, The New State with its endorsement of deliberative democracy is mentioned but neither highlighted nor elaborated. We also cited her in our book, Social Administration (Lohmann \& Lohmann, 2002). 
Mary Parker Follett as a deliberative theorist. Finally, we will note briefly and in passing the roles played by a major American philosopher, John Dewey and another participant in the community schools movement - a forgotten West Virginia progressive education reformer, L.J. Hanifan, who has been only been recognized within the past decade as the original American source of the concept of social capital. ${ }^{16}$

\section{Conventional Wisdom}

The conventional wisdom on Addams, Dewey, Follett and even Hanifan is variable: Addams is currently an iconic figure in American culture as well as social work, although many inside social work and beyond seem uncertain as to why she is important, and it is not unheard of for students to assign her joint responsibility along with Mary Richmond for the development of casework. Her role as a pracademic is internationally recognized; a bona fide intellectual and one of the few moderns to invent a distinctive intellectual and political/civic milieu outside the university. Dewey over much of his 60year public career was the quintessential American philosopher; the Emerson of his century. Social work was one of numerous fields on which Dewey played a major defining role before he largely disappeared from public view following his death in the 1950s. His work only began to reappear as of major importance forty years later, in part because of the attention of European intellectuals like Habermas. The other two figures have been largely consigned more or less permanently to the recycling bin of history. Hanifan is currently making a cameo appearance in connection with his pioneering work on social capital, while Follett, appears to have gone through several cycles of being remembered and forgotten again. ${ }^{17}$ When she is remembered today, it is most often as a pioneer of management theory. Her early career is usually presented as a set of esoteric academic and theoretical contributions beginning with a study of the U.S. House of Representatives (1896) and what she termed The New State (1920), and her "mature" pracademic work in management and business organization (1942).

In connection with his research on the role of social capital in civil society Robert Putnam rediscovered the completely unknown Hanifan and his early formulation of the theoretically important concept of social capital. (Putnam, 2000, p. 19) What was not noted by Putnam is the degree to which Hanifan's contribution was also a pracademic one within the same tradition as Addams, Follett and Dewey. He was a functioning state education official (a "bureaucrat") working with rural, Appalachian schools and seemingly under

\footnotetext{
16 Stereotypes can be very strong; so, strong, in fact that the improbability of a vital, active rural progressive movement in the mountain state prior to the economic devastation of the 1930s1970s was probably an active factor in the loss of Hanifan from the historic record.

17 The periodic "new editions" (re-issuances, really, since the author is deceased and hasn't made any revisions) of The New State in 1965 and 1998 seem to have temporarily brought her back into view before she slipped back into the mists yet again.
} 
the influence of the same set of progressive ideas about neighborhoods, groups, community action, education and democracy that energized Follett, Addams and Dewey. This connection alone should be enough to forge a strong theoretical link between social capital as trusting relationships and networks, the civil society tradition and deliberative democracy theory.

In addition, Hanifan appears also to have been the first to publish an insight that schools are the community centers in rural communities - one of the most powerful and generally accepted principles of contemporary rural social work. (Hanifan, 1916; Lohmann \& Lohmann, 2005) Despite the continuing vigor of the ideas he first presented (and again, the somewhat stilted prose), Hanifan remains unacknowledged by many, even after Putnam's rediscovery in $2000 .{ }^{18}$

There has been a genuine renaissance of interest in democratic political theory in recent decades ${ }^{19}$, and within that upsurge, a growing number of writers have focused not just on democratic theory, but on deliberation in particular. ${ }^{20}$ Gutmann and Thompson (2002) is one of the most widely cited recent theoretical works in this area. ${ }^{21}$ They conclude:

"Deliberative democratic theory is better prepared to deal with the range of moral and political challenges of a robust democratic politics if it includes both substantive and procedural principles. It is well equipped to cope with the conflict between substantive and procedural principles because its principles are to varying degrees morally and politically provisional."

18 In late 2007, just before Roger Lohmann posted a brief biographical statement about him on a web site, a Google search produced not a single online mention anywhere. (Someone has to be well-forgotten to produce 0 Google hits!) As more information has became available, he posted a fuller entry based on archival research - complete with picture - on the Citizendium.org wiki site. In 2009, as this is written, the number of internet hits on Hanifan had risen to just over 5,000 , which is still well below the numbers generated by a number of obscure American writers who were his contemporaries, like Lofcadio Hearn $(35,000)$ and Ole Rolvaag $(20,000)$.

19 Strictly speaking, as already noted, it is a somewhat peculiar renaissance in that many writers appear so genuinely unaware that the topic under study is being re-opened rather than a subject of original inquiry.

20 In the view of some, this renaissance has purely theoretical origins. In particular, John Rawls' Theory of Justice (2005) is often cited as the fountainhead. This alone might account for the ahistoricism, since Rawls approach was a noted Kantian one, working in the realm of 'pure' ideas. For others, the inspiration is to be found in the real world events of the collapse of the Soviet empire and the accompanying collapse of communism as a theoretical domain. Whatever the reasons, even a partial list of the major contributions would include theorists like Rawls (1993; 2001; 2007); Anthony Arato and Jean Cohen (1992); Benjamin Barber (1984; 1988); Kymlika (1995); Rodin (2003) and Sandel (1996) and numerous others including many cited in the bibliography at the end of this volume.

21 The practical and pracademic contributions of Amy Gutmann as president of Princeton University are possible subjects for future consideration. Here the focus is purely on her theorizing. 
By reading their phrase "substantive and procedural principles" as referring, in turn, to theory and practice, one can interpret this powerful statement as arriving from a theoretical direction at what we are calling the pracademic perspective on deliberative democracy. There is, they say, an important role for theory in arriving at principles like those of reciprocity but political theory cannot remain authentically democratic if it limits or abridges the legitimate decision-making powers of autonomous citizens. But, how are we to assure this? Their answer is clear:

"Deliberative democratic theory can avoid usurping the moral or political authority of democratic citizens and yet still make substantive judgments about the laws they enact because it claims neither more, nor less, than provisional status for the principles it defends." (p. 176)

In this key phrase "provisional status" the reader is reminded here of Benjamin Barber's separation of an autonomous realm of political knowledge independent of theory or philosophy (1988):

"The historical aim of political theory has been dialectical or dialogical: The creation of a genuine praxis in which theory and practice are ... reconciled, and the criteria yielded by common action are permitted to inform and circumscribe philosophy no less than philosophical criteria are permitted to constrain the understanding of politics and informed political action. Yet in much of what passes for political philosophy in the age of liberalism, reductionism and what William James called 'vicious abstractionism' has too often displaced dialectics and dialogue. The outcome has been neither political philosophy nor political understanding but the conquest of politics by philosophy.” (Barber, 1988, 4)

Every practitioner of deliberation and dialogue will wind up struggling with the implications of that idea and its implications at some point regardless of their degree of theoretical sophistication. At bottom, it alludes to the long-ago efforts by Dewey to "recover" philosophy, and suggests an essential paradox in the writings of Jane Addams, not to mention in all of progressive thought from Herbert Croly (2005) on: authentically democratic practice must be guided by theory, but cannot be controlled by the view of political philosophers, government experts or professionals without becoming a mere puppet show of the theorist/puppet-masters. Perhaps no one in the first half of the twentieth century was more aware of this than Jane Addams.

\section{Jane Addams}


Political philosophers, social scientists and other non-social workers have in recent decades rediscovered the historic Jane Addams in major ways. In addition to the many claims made on her by social work, she has been said to be a Chicago-school sociologist (Deegan, 1984; 1988), feminist theorist (Fischer, Nackenoff and Chmielewski, 2009), , public administration theorist (Stivers, 2009), pragmatist philosopher (Menand, 1997), intellectual (Lasch, 1986), social philosopher (Lasch, 1965) and peace theorist (Elshtain, 2002) to name just a few. Of course, reasonable cases can be made for all of these positions, and they are certainly not (as some of their advocates appear at times to argue, mutually exclusive.)

For Fisher, Nackenoff and Chmielewski (2009) Addams is "an extraordinary activist and thinker in many ways ahead of her time". (p. 1) Unfortunately, too much of the Addams renaissance distorts the pracademic Addams for the authors' purposes and, in particular, seeks to distance her from social work even as it succumbs to the priority of theory that Barber derides. Was Jane Addams all of the things these authors suggest? Yes, almost certainly. But did she also have a deep and abiding commitment to the social work of her day? That also is undeniable. And, as part of the overall package Addams (1860-1935) had a strong record of commitment to deliberation and dialogue and her own unique blend of deliberative democracy theory that for decades after her death was dismissed by philosophers and others as naïve and idealistic, but which new generations keep returning.

From our vantage point, the very idea of young, educated, bourgeois "urban settlers" Addams, like Ellen Gates Starr and the others who followed her establishing residence in inner city neighborhoods of poor immigrants was a fundamentally dialogical project: One major reason Hull House residents settled was deliberative: to speak, listen, learn and teach. Certainly, they did other things as well (although a great deal less "relief", casework and family visiting than many social work students are comfortable with).

According to their own reports, one of the first things that Addams and Ellen Gates Starr did upon moving into the Hull House in 1889 was to hold what might variously be termed an open house, a reception, a meet and greet or, more formally, a salon for the purpose of meeting and talking with residents of the neighborhood. One would be hard pressed to find a more clear-cut example of a dialogical democracy initiative anywhere.

From the very start, Hull House was tied to a basic model of deliberative democracy. This is evident in the three "ethical principles" that Addams and Starr endorsed at the beginning: "to teach by example, to practice cooperation, and to practice social democracy, that is, egalitarian, or democratic, social relations across class lines." (Knight, 2005, p. 182) Hull House was not an experiment in policy advocacy or lobbying Congress or the Illinois legislature, 
nor did they aspire to "practice cooperation" like the Roycrofters by forming a production cooperative. It was, from the start an effort at cross-class deliberation as part of a larger experiment in cooperation as conflictreduction and equality and social democracy in social relations.

This Hull House model of deliberation and dialogue continued to evolve throughout Jane Addams long career, as pracademic projects are wont to do. The Hull House model, like Deweyian ideas on social democracy and Follett's model articulated in The New State, also influenced the development of social work education and practice with respect to groups, the desirability of face-toface group interaction of people with differences, and in the basic commitment to group and organizational democracy.

\section{John Dewey}

Cause and effect are almost impossible to pull apart in the case of the mutual effects upon one another of Addams and her long-time friend and colleague John Dewey. Both through Addams and on his own, Dewey was also a major contributor to the early (and contemporary) social work model of deliberation in addition to his contribution of the social work problem-solving model. Until well into the 1970s, social work texts routinely cited a number of Dewey's articles, notably the 1910 "How We Think". Dewey began his long career in the $19^{\text {th }}$ century as a Hegelian idealist but early in the $20^{\text {th }}$ century began to emerge as one of the founders of a distinct American pragmatism. Festenstein, in the online Stanford Encyclopedia of Philosophy suggests a number of characteristics that survived this major transition in Dewey's thought. It should be easily and immediately apparent both that these are deeply embedded in social work and lay the groundwork for the social work model of deliberative democracy:

"holism about the individual; anti-elitism; democratic participation as an aspect of individual freedom; and the unconventional view of democracy as a form of relationship inherent not merely in political institutions but in a wide range of social spheres."

He might have added as well, the importance of social experiment, personal change grounded in education, and strong commitment to the kind of communcation-based social relations that Habermas, among others, recovered from Dewey. These same beliefs are also attributable to Jane Addams, Follett, Hanifan and to much of early social work. Although Dewey is still difficult to read and interpret half a century after his death, there should be little doubt that his influence upon the evolution of social work eduction and practice was strong, and that a distinctly Deweyian model of deliberative and democratic social relations was an important part of that influence. 


\section{Mary Parker Follett}

The evidence in support of Mary Parker Follett (1868-1933) as an early pracademic of deliberation and dialogue is equally decisive, even though she is far less known and celebrated than her contemporaries Addams and Dewey. Follett's career, as noted, is often divided into two phases, but can more convincingly divided, from the standpoint of deliberative democracy, into three, each marked by one of her three principal publications. Her career began with a conventional period of academic study of history with (like Dewey, and the theorists of the British welfare state a strong measure of Hegelian, idealist) philosophy. These influences came together in 1896 when she authored a solid and well-received institutional analysis of the U.S. House of Representatives. Following her inability to secure an academic position, the second period in Follett's career began with nine years of community social work practice (1900-1908) and culminated in her second and most remarkable book, The New State. Group Organization, the Solution of Popular Government, published in 1918. In the third and final phase of her career, Follett concentrated on applying insights gained from her social work phase to democratizing business organizations, as evidenced in the collection of essays published posthumously in Dynamics of Administration (1942). ${ }^{22}$

Since her death two years before Addams, Follett has remained a major figure in administrative/management theory, but both the pivotal importance of her social work experience and her status as a political philosopher of deliberative democracy periodically fall into anonymity. For this reason, we need to look more closely at Follett's contributions to deliberative democratic thought.

Follett's 1896 House study (and her even less known biography of Henry Clay) "conformed to a developing consensus in professional political science" to accept the growing power of the national government and the declining relevance of older forms of popular self government like New England town meetings. (Mattson, xxxiii)). In short, like other Progressives (notably Herbert Croly and Walter Lippman) Follett argued that the civil society of de Tocqueville was obsolete; necessarily pushed aside by a representative democracy of elected officials and administrative experts deemed more suitable for an industrial society in which citizenship consisted principally of voting in elections and watching.

In her second phase, this view was not only modified but completely upended in a remarkable transformation. Those most familiar with Follett's

\footnotetext{
${ }^{22}$ Conceivably, one might suggest another phase in her career associated with Follett's 1924 publication of Creative Experience, although this is probably best assigned to her final business management phase, just as the early (unpublished?) biography of Henry Clay is easily assigned to her "represented government" phase along with the 1896 study of the House.
} 
career generally agree there is only one factor to explain her radical shift away from representative democracy to the view expressed in The New State, and that is her involvement in social work. "By the 1910s," Kevin Mattson, editor of the 1998 edition of The New State says, "Follett had radically changed her political ideas... The same woman who had once written that 'the democracy most to be desired' was the 'representative assembly,' now argued that 'representation is not the main fact of political life; the main concern of politics is modes of association." (xxxix) She also wrote: "you cannot establish democratic control by legislation...; there is only one way to get democratic control - by people learning how to evolve collective ideals." (xxxix)

Follett's nine years of social work practice (2000-2008) in the Boston community center movement are generally acknowledged as the sole motivation for this profound shift in her theoretical orientation. Mattson tells us:

"Mary Parker Follett followed in Jane Addams' footsteps, always working within the parameters set by a society that allowed only a circumspect involvement of women in public affairs. Ironically, Follett's lack of academic opportunities provided her with new forms of experience that radically altered her intellectual ideas about democracy. (Emphasis added) Experience taught Follett a great deal more about politics than a career in academia ever could." (Mattson, 1995. xxxv-xxxvi)

Follett was not an urban settler in the Addams mode. She worked in Boston in the related community schools movement founded by Robert A. Woods in Rochester NY (Woods, 1971). The effort was to re-define schools as community centers open to the social and civic participation of neighborhood residents. This was the same movement that influenced our fourth (and least known) figure. L. J. (Lyda Judson) Hanifan was engaged in similar community-school efforts as Superintendent of Rural Instruction in West Virginia (1912-1920). Before looking further at Hanifan, however, we need to look closely at Follett's New State.

\section{Follett's New State}

Benjamin Barber, political philosopher of deliberative democracy and author of Strong Democracy: Participatory Politics for a New Age, (1988) which is itself a major theoretical contribution to deliberative democracy theory, calls Follett's The New State: 
"an extraordinary paean to a stronger more participatory form of American democracy that was drawn in equal parts from Follett's academic acumen as a student of democratic theory, Royce and Hegel as well as Laski and Cole, and from her own personal experience in local democracy and community organization." (Barber, 1995, xv)

In other words, like Addams and Hanifan, Follett too has solid pracademic credentials. Barber goes on to offer this assessment of the book:

"In The New State, she writes what must be regarded as an American classic of participatory democracy. She keeps arms length from nationalist accounts without falling into parochialism, and she distinguishes deliberative, education-grounded forms of direct democracy from mob-rule caricatures first drawn and then assailed by Lippman and other liberal critics of too much participation." (Barber, 1995. xv)

As Mattson observes, “"For Follett, as with other social centers activists, the democratic citizen was committed to public dialogue" (1995, 313). As part of her transformation, Follett replaced her earlier nationalist emphasis with a local/community orientation still recognizable by all social workers: "In a neighborhood group," Follett insisted, "you have the stimulus and the bracing effect of many different experiences and ideals." (Follett, 1918, p.196)

Yet rather than signaling the beginning of a major change in thinking about American democracy, both the community centers movement and Follett's (as well as Hanifan's) contributions came at the very end of the progressive era and very soon was largely ignored and forgotten. Thus, her career took yet another turn. "After the decline of the social centers movement after World War I - a decline due largely to the mistakes made by activists and thinkers in the movement itself - Follett became interested in modern business management." (Mattson, 1995, lviii)

The essence of her perspective was a clustered hierarchy of associations, beginning with neighborhood-based face-to-face groups practicing deliberation and democratic social relationships. Her nestedinstitutions view (groups within organizations within neighborhoods within communities within society) is still evident in the social work education standards today. Yet, even as Follett went on to radically transform theories of business administration and organizational life, her contributions to a stong and vital social work-based original perspective fell into a neglect it has yet to fully recover from.

\section{J. (Lyda Judson) Hanifan}

We turn now to the final example of a local pracademic and contemporary of Addams, Dewey and Follett who also played a crucial role in 
the pracademic conceptualization of deliberative democracy and was also lost to history for decades, and whose major contribution to deliberative democracy and social work may yet lie in the future. L. J. Hanifan (18791931) from his position of Superintendent of Rural Instruction for the West Virginia Department of Education, authored a number of books and articles that enable us to place him squarely in the same community centers movement as Follett. (Hanifan, 1916; Hanifan, 1920) They also establish him, as Putnam noted, as the original American pracademic to formulate the concept of social capital, a concept tied elsewhere in this volume to deliberative theory and practice. ${ }^{23}$ From the vantage point of social work, he may also be the first in print to give voice to a principle still fundamental to rural social work practice: that local schools are the vital community centers of rural communities.

More than 70 years after his death, Hanifan's writings on social capital and community centers were rediscovered by Robert Putnam who discussed them in Bowling Alone (2000, p. 19). The known facts of Hanifan's life and career as a West Virginia progressive are still sketchy and need not be repeated here. ${ }^{24}$ Hanifan's writings are clearly those of a pracademic (He was one of eight original members of the WV Department of Education and involved in policy efforts setting high school curriculum requirements for the state). He was also clearly writing in the context of the same community centers movement as Follett. Between 1912 and 1920, Hanifan authored ten known articles, chapters and reports that not only are the first publications identifying the concept of social capital, they also link him with the community schools movement, and as a potential source in rural social work. In all, five of Hanifan's ten known publications, including three journal articles and two books, deal with neighborhood (in his case, rural rather than urban neighborhoods and communities) and the concept of schools as community centers.

Hanifan's definition of "social capital" (1916) reflects not only a compatible orientation to Addams, Dewey and Follett but also an affinity for, if no direct organizational ties to, a social work orientation:

"The tangible substances [that] count for most in the daily lives of people: namely good will, fellowship, sympathy, and social intercourse among the individuals and families who make up a social unit. ... The individual is helpless socially, if left to himself. If he comes into contact with his neighbor, and they with other neighbors, there will be an accumulation of social capital, which may immediately satisfy his

\footnotetext{
${ }^{23}$ Hanifan's 1916 journal article and a chapter in his 1920 book entitled "Social Capital" mark his contribution many decades before academic theorists like Pierre Bourdeau (1986), James Coleman (19XX) and others cited as originators in the theoretical literature.

${ }^{24}$ For those who may be interested, everything currently known about Hanifan is published on a web page at: http://en.citizendium.org/wiki/L.J._(Lyda_Judson)_Hanifan
} 
social needs and which may bear a social potentiality sufficient to the substantial improvement of living conditions in the whole community. The community as a whole will benefit by the cooperation of all its parts, while the individual will find in his associations the advantages of the help, the sympathy, and the fellowship of his neighbors."

(Quoted from Putnam, 2000, p. 19)

Social work is only beginning to take notice of the idea of social capital, and to date there has been no discussion linking social capital to the deliberative interests of the field, but making that connection is a very small intellectual leap.

\section{Contemporary Social Work as a Deliberative Environment}

The ideas of Dewey, Addams, Follett and others like Hanifan have been so deeply engrained in social work that the entire profession of social work is organized as a democratically organized, deliberative body, where decisions are seldom made by voting, but on the basis of emergent consensus following democratically-organized group discussion. There are many groups, organizations and focused publics ${ }^{25}$ involved in the social construction of contemporary social work as an activity, programmatic enterprise and institution and each is concerned in its own way with issues of definition, identity and boundaries of professional education and practice. The very fact of this plurality means that important elements of dialogue and deliberation are built into the theory and practice of modern social work, as they are of many disciplines and professions.

Social work in the early $21^{\text {st }}$ century both as a profession and as an academic discipline has established itself more securely than ever before. It is at least partly in the nature of the civic republican conception of professions and disciplines that these various organizations and entities that define modern social work can be seen as autonomous, self-governing collectivities of autonomous, self-governing persons. ${ }^{26}$ Indeed, from a deliberative theory

\footnotetext{
${ }^{25} \mathrm{~A}$ focused public is defined here as a body of person, sufficiently large that members are not personally known to one another but would under most circumstances have some sense of mutual recognition, who do not all belong to the same organization, yet share some common values, mission or interests. In this sense, the professional community of social work identified in the first paragraph of this article is a focused public and AARP, the American Association of Retired Persons, is not even though it involves more people and is similarly purposive. The term is often used in conjunction with at least one more adjective as in consumer-focused public, science-focused public, new-focused public and a wide variety of topic-focused publics.
}

26 The civic republican tradition in political philosophy tends not to be acknowledged by name in contemporary social work but is deeply imbedded in the self-definition of the profession in many ways; none is more fundamental than the social work model of personal growth and development influenced by the social environment. This model is completely consistent as a matter of political 
perspective, social work professionals can be seen as autonomous persons working within a self-governing profession and clients can be seen as persons wishing to achieve greater personal autonomy. This is a key element of the worker- (service or supply) side of the social work emphasis on human development and the social environment. In order for social workers to make sense of what they are doing, as well as evaluating when they have done it successfully, there must be some measure of widespread agreement on the nature, scope and dimensions of the activity of social work. While for many "authorities" this is seen as a preliminary - and one time - consideration, the reality is that deliberative and dialogical processes focused on two disarmingly simple questions - What is social work? Who is a social worker? - have been matters of almost continuous dialogue and deliberation within the field for at least the last century.

The institution of social work in all of its diverse manifestations has grown to include a bewildering variety of licensed and certified professionals, clients, volunteers, paraprofessionals, at least some of whom are organized into various self-governing membership organizations, mutual aid and selfhelp groups. The contemporary social work profession is a highly complex entity. It includes not only the 167,000 or so members who belong to the National Association of Social Workers (NASW), but also a large number of additional non-NASW members licensed for the practice of social work by their respective states, and all of the graduates of the nearly $200 \mathrm{MSW}$ and more than $500 \mathrm{BSW}$ programs in colleges and universities accredited by the Council on Social Work Education (CSWE). Moreover, social work practice and education in the United States have become the working models for the organization of social work in many other parts of the world, through such organizations as the International Association of Social Work, the

International Association of Schools of Social Work and assorted national and regional professional and academic associations in different countries.

Because there are so many groups, organizations and focused publics involved in the social construction of professional social work as an enterprise and institution and each is in some way concerned with managing the definition, identity and boundaries of professional education and practice, important elements of dialogue and deliberation are built into the very warp and woof of modern social work, as it is of other professions and academic disciplines.

philosophy with the civic republican model of democratic community made up of self-directing individuals in self-governing communities. This is due in large measure to the influence of several generations of influential writers and thinkers including Jane Addams and Mary Richmond, and many others in the charity organization society and settlement house movements and the more recent movement to define and articulate the profession. It goes without saying that the civic republican (small $\mathrm{R}$ ) element in social work is no more a matter of partisanship or party than the equally deep professional commitment of social workers to democratic (small D) community with which it interfaces seamlessly. 
The delegate assembly of NASW, the accreditation commission of CSWE and the diverse state licensure bodies are routinely involved in fundamental matters and concerns of defining and elaborating what is regarded as legitimate practice and preparation for practice. Dialogue and deliberation are also fundamental to the constitution of social work education and practice. A thoroughgoing value commitment - indeed, one of the core social work values in the view of social work educators and the official code of ethics established by NASW - is the idea of self-determination, for the profession as well as for clients. ${ }^{27}$

However, social work practice and all of the assorted national, international, state and local associations that support it are highly complex and contingent matters and coherent, ongoing operations of the profession are dependent in part on continuous, on-going discussions.

In all of these senses, dialogue and deliberation in their general meanings are built into the very organizational fabric that goes into creating, identifying and sustaining the institutions of modern social work. It is important to note, however, that the adjectives, public and sustained in the title of this book are very important: that not all of the deliberations that construct social work are public and not all of the dialogue is sustained. Some are the proprietary talks of specific organizations and interests, and some are very sporadic and short-term.

However, careful reading of the other chapters in this book will make clear to most readers that the specific models of public deliberation and sustained dialogue have many applications in social work. Perhaps nowhere is this more evident than in the long and continuing history of discussion of that momentous question: What, exactly, is social work? Practitioners, academics, employers, students, the NASW Delegate Assembly, and many others have periodically revisited this question through deliberations ongoing over most of the past century. This is also true in creating and sustaining public understanding of the rationales for the profession and for professional practice, and for resolving some of the many existential dilemmas that arise in application of the values of the social work profession to daily life on an ongoing basis.

\section{Conclusion: Implications for Curriculum}

Given the role of social work curricula in specifying the nature and parameters of social work practice, one might ask how deliberation and dialogue have been addressed in the curriculum of accredited social work education programs. In order to fully appreciate that relationship, it may be

27 Self-determination in this sense might be seen as merely the civil, apolitical aspect of what the political theory literature treats as self-governance or autonomy. (See Elstub, 2008) 
appropriate to briefly describe how the curriculum influences social work practice.

One of the changes over the last few decades in the field of social work is the increasing requirement that persons identifying themselves as social workers be licensed as such. While the requirements for licensure differ from state to state, one common thread is that to be eligible for licensure, a candidate must have graduated from a Council on Social Work Education (CSWE) accredited program. Thus, the expectations for accredited programs influence who is recognized as a social worker and the kind of practice he/she may be prepared to do. Thus, in the present and future, engagement with deliberation and dialogue by social workers is, to a significant degree, influenced by some measure of recognition of these processes in accredited curricula.

The curricular requirements for all accredited programs are found in the Educational Policy and Accreditation Standards of the Council on Social Work Education. The most recent standards, adopted in 2008 are available online at http://www.cswe.org/NR/rdonlyres/2A81732E-1776-4175-AC4265974E96BE66/0/2008EducationalPolicyandAccreditationStandards.pdf.

While neither the current nor the preceding standards explicitly use the words deliberative or dialogue, it is clear from some of the standards that there is a continuing legacy of the Jane Addams/Mary Parker Follett traditions noted above and some measure of deliberation and dialogue is expected in social work education. One such example may be found in Educational Policy 2.1.10. In that section, one finds such statements as “ Professional practice involves the dynamic and interactive processes of engagement, assessment, intervention, and evaluation at multiple levels." The terms dynamic and interactive certainly refer to processes that are a part of deliberation and dialogue. That some of those multiple levels involve direct engaged Don't understand “direct engaged." Direct engagement?, etc. with clients is clear, but it is also clear from the context of social work involvement with broader cultural values, social problems, and social policy that these multiple dynamic and interactive processes also apply to group and community deliberation and dialogue processes. For example, the engagement of the campus sustained dialogue movement with issues of racism on campus as described by Saunders and Parker and Tukey and Nemeroff and Van Til in this volume is an obvious extension of social work concerns.

Subsections of this particular standard also described a specific deliberative process. Section 2. .10 (a) on Engagement includes "develop a mutually agreed on focus of work and desired outcomes." Section 2.1 .10 (b) indicates the need to " develop mutually agreed - on intervention goals and 
objectives. Neither of these would be possible without engagement in processes of deliberation and dialogue.

The continuing importance of deliberation and dialogue for social work education may also be found in Educational Policy 3.0, which refers to " the culture of human interchange; the spirit of inquiry; this support for difference and diversity" among other qualities that inform a student's learning and development. Thus, while the terms deliberation and dialogue do not appear in CSWE accreditation standards, it is clear that such activities are compatible with and even expected by the standards.

The dialogue that is expected is demonstrated in several ways as a student progresses through the social work curriculum. First, it likely demonstrated in the classes taken by a student via the interaction among faculty members and students. Such classes typically place an emphasis on students providing feedback on the concepts introduced. In fact, to facilitate such feedback, it is not uncommon for students and the faculty member to sit in a large circle facing each other as a means of enhancing dialogue. The use of this kind of seating arrangement also demonstrates equality among the participants in the discussion.

Social work education often makes use of group assignments in classroom work. This is not a matter of accident or coincidence, but a direct result of the continuing recognition in social work education of the importance of group process; a recognition that is directly traceable back to Jane Addams, Mary Parker Follett and others. As Follett observed in The New State, group process inevitably requires deliberation and dialogue among the participants. While students sometimes object that work is not evenly distributed among group members when such groups are used, the continued use of them indicates the importance placed on dialogue and developing the skills needed to engage in dialogue.

The most recent Accreditation Standards also incorporate the concept of a signature pedagogy for social work which is field instruction. The use of that pedagogy in social work, grounded as it is in the historic insights of Dewey, Addams and Follett, also emphasizes the importance of deliberation and dialogue among student(s) and field instructor(s) and classroom faculty. In recognition of this, many undergraduate and graduate social work programs have adopted the model of the field seminar in which aspects of students' experience (in the words noted above) are engaged, assessed and evaluated in an educational intervention. The process begins when the student and his/her field instructor develop the learning objectives for the field experience. Through that process, they discuss both the curricular expectations and the strengths and learning needs of the student. Thus, field expectations for a particular student reflect deliberation and dialogue about that student's strengths and limitations. 
The dialogue also continues outside the seminar when the student and field instructor meet periodically to discuss the student's progress. Those meetings may result in consensus that a given field objective has been met. They may also, however, result in extended discussions about the progress a student has achieved in a given area. Similar discussions would occur between the student and field instructor about the student's clients and their programs. Such discussions inevitably involve deliberation and dialogue.

Field experiences also involve a more formal, written assessment of student progress. While the particular methods used may vary from social work program to social work program, it is not uncommon for both the student and field instructor to rate the student's performance in specified areas and then discuss where their individual ratings agree and disagree. As these few examples indicate, the signature pedagogy of social or involves significant deliberation and dialogue. That approach is demonstrated in both classroom and field. 


\section{References}

Barber, B. R. (1988). The Conquest of Politics: Liberal Philosophy in Democratic Times. Princeton NJ: Princeton University Press.

Barber, B. R.. The Conquest of Politics: Liberal Philosophy in Democratic Times. Princeton, New Jersey: Princeton University Press. 1988.

Barber, B. R.. "Mary Parker Follett as Democratic Hero." (Forward) Mary Parker Follett. The New State; Group Organization, The Solution to Popular Government. University Park: Pennsylvania State University Press. 1998

Bourdieu, P. (1986). The forms of capital. In J. Richardson (Ed.), Handbook of Theory and Research for the Sociology of Education. Westport, CT: Greenwood Press.

Cohen, J. L., \& Arato, A. (1992). Civil Society and Political Theory. Cambridge MA: MIT Press.

Deegan, M. J. (1984). The Sociology--Not Social Work--of Jane Addams. Proceedings from Association of Humanist Sociologists, Chicago IL.

Deegan, M. J. (1988). Jane Addams and the Men of the Chicago School: 18921918. New Brunswick NJ: Transaction Press.

Dewey, J., Morris, D., \& Shapiro, I. (1993). John Dewey: The political writings. Indianapolis: Hackett Pub. Co.

Elshtain, J. B. (2002). Jane Addams and the dream of American democracy : a life. New York: Basic Books.

Elstub, S. (2008). Towards a deliberative and associational democracy. Edinburgh: Edinburgh University Press.

Festenstein, Matthew, "Dewey's Political Philosophy", The Stanford Encyclopedia of Philosophy (Spring 2009 Edition), Edward N. Zalta (ed.), $\mathrm{URL}=<$ http://plato.stanford.edu/archives/spr2009/entries/dewey-political/>.

Fischer, M., Nackenoff, C., \& Chmielewski, W. E. (2009). Jane Addams and the practice of democracy. Urbana: University of Illinois Press.

Follett, M. P. (1920). The New State. London: Longmans, Green.

Follett, M. P. (1942). Dynamic Administration: The Collected Papers of Mary Parker Follett. New York: Harper \& Row.

Follett, Mary Parker. The New State: Group Organization the Solution of Popular Government. University Park, Penn: The Pennsylvania State University Press, 1998.

Gutmann, A., \& Thompson, D. (2002). Deliberative democracy beyond process. Journal of Political Philosophy, 10(2), 153. 
Habermas, J. (1984). The theory of communicative action. Boston: Beacon Press.

Hanifan, L. J. (1916). The Rural School Community Center. Annals of the American Academy of Political and Social Science, 67, 130-138.

Hanifan, L. J. (1920). The community center. Boston, New York etc.: Silver Burdett \& company.

Knight, L. W. (2005). Citizen : Jane Addams and the struggle for democracy. Chicago: University of Chicago Press.

Kymlicka, W. (1995). Multicultural citizenship : a liberal theory of minority rights. Oxford

Lasch, C. (1986). The new radicalism in America, 1889-1963 : the intellectual as a social type. New York: Norton.

Lohmann, N., \& Lohmann, R. A. (2005). Rural social work practice. New York: Columbia University Press.

Lohmann, R. A., \& Lohmann, N. (2002). Social administration. New York: Columbia University Press.

Mansbridge, Jane. ”Mary Parker Follett: Feminist and Negotiator. A

Foreward." in Mary Parker Follett. The New State; Group Organization, The Solution to Popular Government. University Park: Pennsylvania State University Press. 1998. xvii-xxviii

Mattson, Kevin. "Reading Follett: An Introduction to The New State. Mary Parker Follett. The New State; Group Organization, The Solution to Popular Government. University Park: Pennsylvania State University Press. 1998

Menand, L. (1997). Pragmatism: a reader. New York: Vintage Books.

Mooney, P. N., \& Eikenberry, A. M. (2006). Beyond public and private: The transformative potential of democratic feminist management. Administrative Theory and Praxis, 28(3), 359-380.

Morse, R. S. (2006). Prophet of Participation: Mary Parker Follett and Public Participation in Public Administration. Administrative Theory and Praxis, 28(1), 1-32.

Putnam, R. D. (2000). Bowling alone: the collapse and revival of American community. New York: Simon \& Schuster.

Rawls, J. (2005). A theory of justice (Original ed. 1971). Cambridge, Mass.: Belknap Press.

Sandel, M. J. (1996). Democracy's Discontent: America In Search of a Public Philosophy. Cambridge: Harvard University Press.

Stivers, C. (2000). Democracy, bureaucracy, and the study of administration. Boulder, CO: Westview Press. 
Weiner, M. (1990). Human Services Management: Analysis and Applications. Belmont CA: Wadsworth.

Westbrook, R. B. (1991). John Dewey and American Democracy. Ithaca NY: Cornell University Press. 


\section{Appendix A}

\section{CORE PRINCIPLES for Public Engagement}

Developed collaboratively by members of leading public engagement organizations. (DRAFT 04-01-09)

Core Principles for Public Engagement! www.thataway.org/2009/pep_project

There are many ways that people can come together to deal with issues that affect their lives. We believe that public engagement involves convening diverse yet representative groups of people to wrestle with information from a variety of viewpoints, in conversations that are well-facilitated, providing direction for their own community activities or public judgments that will be seriously considered by policy-makers and/ or their fellow citizens.

It is our stance that quality public engagement must take into consideration seven core principles if it is to effectively build mutual understanding, meaningfully affect policy development, and/or inspire collaborative action among citizens and institutions.

The following seven principles overlap and reinforce each other in practice. They serve as ideals to pursue and as criteria for judging quality. Rather than promoting partisan agendas, the implementation of these principles generates authentic stakeholder engagement around public issues.

\section{The Seven Core Principles}

1. Preparation - Consciously plan, design, convene and arrange the engagement to serve its purpose and people.

2. Inclusion - Incorporate multiple voices and ideas to lay the groundwork for quality outcomes and democratic legitimacy.

3. Collaboration - Support organizers, participants, and those engaged in follow-up to work well together for the common good.

4. Learning - Help participants listen, explore and learn without predetermined outcomes -- and evaluate events for lessons.

5. Transparency - Promote openness and provide a public record of the people, resources, and events involved.

6. Impact - Ensure each participatory effort has the potential to make a difference.

7. Sustainability - Promote a culture of participation by supporting programs and institutions that sustain quality public engagement.

This list represents a consensus in the field of dialogue and deliberation, but most practices tend to emphasize or apply these principles differently or to reach beyond this basic consensus in one way or another. To learn more about such diverse understandings and applications, consult the online version of these guidelines at 
www.thataway.org/2009/pep_project.

Finally, we believe the use of technology should be generally encouraged whenever appropriate to enhance and not impede these seven values -- and also that these seven principles apply to both online and offline efforts. However, there is not yet consensus in our field on standards for the use of technology that would warrant the inclusion of specific online or electronic guidelines in this document.

The National Coalition for Dialogue \& Deliberation (NCDD), the International Association of Public Participation (IAP2), and the Co-Intelligence Institute are leading this collaborative effort to develop a standard set of principles we hope organizations in the field of public engagement can agree on. With new attention and emphasis on collaboration, participation, and transparency thanks to the leadership and vision of the Obama administration, we feel it is more important than ever to provide clarity about what we consider to be quality public engagement. Please feel free to contact NCDD's director, Sandy Heierbacher, at

sandy@thataway.org with questions

Core Principles for Public Engagement! www.thataway.org/2009/pep_project

2 